$\underline{\text { Review Article }}$

\title{
A REVIEW ON PHYTOPHARMACOLOGICAL ACTIVITY OF ALPINIA GALANGA
}

\author{
SHIMAILA ERAM, MD. MUJAHID*, PARAMDEEP BAGGA, MUHAMMAD ARIF, MD. AFROZ AHMAD, ARUN KUMAR, \\ FAROGH AHSAN, MD. SOHEL AKHTER
}

Faculty of Pharmacy, Integral University, Lucknow

Email: mujahid@iul.ac.in

Received: 14 Dec 2018 Revised and Accepted: 26 Jan 2019

\begin{abstract}
Alpinia galanga plant which is associated with family Zingiberaceae is mainly scattered in tropical areas and widely known for ethno medicine. Against fungi and bacteria rhizome extract have a maximum inhibitory effect. Alpinia galanga plant is used in medicine and in food preparation. Rhizome extract of Alpinia galanga have high phenolic and flavonoid contents when compared to leaf extract. Because of elevated phenolic and flavonoid content in rhizome extract of Alpinia galanga there is noticeable antimicrobial as well as radical scavenging potential. It is a well-known official drug thought out the country as integrated contribution of nature. It is commonly used for the management of eczema, coryza, bronchitis, otitis interna, gastritis, ulcers, morbilli and cholera, pityriasis versicolor, to clear the mouth, emaciation. The different parts of the plant have various effects like antifungal, antiprotozoal, antiplatelet, antiviral, antidiabetic, immunomodulatory, antibacterial, anti-oxidant effects, hypolipidemic and many others. The essential oil of A. galanga identified 1, 8-cineol as a bioactive agent having antifeeding activity. An aqueous acetone extract of fruit of Alpinia galanga shows inhibitory effect on melanogenesis (formation of melanin). By using different methods, active constituent namely, 1'acetochavicol acetate in hexane extract of Alpinia galanga rhizome was investigated for their corrosion inhibition properties. The current review add significant information about its, pharmacological activities, medicinal properties and phytochemical investigations as a traditional drug to cure for a number of diseases. Every fraction of the plant has valuable properties that can deliver humanity. The complete plant will be broadly investigated for further future prospective.
\end{abstract}

Keywords: Alpinia galanga, Pharmacology, Phytochemistry, Traditional use, Chemical constituent

(c) 2019 The Authors. Published by Innovare Academic Sciences Pvt Ltd. This is an open access article under the CC BY license (http://creativecommons.org/licenses/by/4.0/) DOI: http://dx.doi.org/10.22159/ijpps.2019v11i3.31352

\section{INTRODUCTION}

Every part of the world, the medicinal plants are becoming popular and their use is increasing day by day in modern society as natura alternatives [1]. At the current juncture, the modernized traditional health care are weighed down with big complications of hazardous medicine, chronic disease, resistant infections, degenerative disorders of ageing and autoimmune disorders, much considerable scientific advances. Besides $70 \%$ of India's 1.1 billion public still, make use of these non-allopathic schemes of medicine [2]. Medicinal plants of zingiberaceae are distributed broadly throughout the tropics, especially in Southeast Asia and were eminent for its unlimited medicinal values. Plants of Zingiberaceae family gives many profitable products for food, dyes, perfume, spices, dyes, artistic and medicines [3]. Alpinia galanga (greater galanga), Alpiniaofficinarum (lesser galanga), Boesenbergia rotunda and Kaempferia galanga, these all four comes in the category of galanga which have a wide range of usage. Amongst these, Alpinia officinarum and Alpinia galanga, usually called Lengkuas, are the most widespread species in the native land of Albay, Philippines.

Alpinia galanga, also known as greater galanga has tuberous and aromatic rootstocks. Flowers are greenish white, $30 \mathrm{~cm}$ Panicles and bracts ovate are lanceolate. Calyx is tubular, unevenly 3 -toothed. Corolla lobes are oblong, largely elliptic, and shortly 2-lobed at the apex, the claw is green, and the blade is white and striated with red, rather more than $1 \mathrm{~cm}$ long. Leaves are oblong, lanceolate, glabrous and green above, paler beneath, to some extent callus white margins. Sheaths are elongated and glabrous while the ligules are undersized and curved. Fruit size resembles likes small cherry, which is orange and red in color [4]. Due to the resemblance in appearance and in taste, the rhizome of galanga looks like ginger. Galanga has the phytochemicals such as Galangin, beta-Sitosterol, Quercetin, and Emodin. They are also the source of iron, vitamins $\mathrm{A}$ and $\mathrm{C}$, sodium [5]. In general, it is associated with ginger which is a well-liked and more known spice, but a closer brief look will give the difference between the two. Galangas have tight outer covering, light in color and have pinkish portions too. Galangas are well-liked in Asiatic as well as in European medieval cooking. Besides as a cooking ingredient, galangas have more to show in future researches. In further parts of the world, the rhizomes are supposed to be used as abortifacient, carminative, anti-tuberculosis and have stimulant properties. They are also used for skin infections such as eczema, ringworm and other skin diseases. Chinese used galangas as to relieve flatulence, dyspepsia, nausea, vomiting, loss of appetite, and motion sickness. Now galangas are used to make perfumes in Thailand [6]

Alpinia galanga consists of major as well as minor chemical constituents which belong to the different class of natural products. The GC-MS analysis showed that the major compounds of galanga extract are 1, 8-cineole, $ß$-bisaboline and $\beta$-selinene whereas minor compounds are selinene, farnesene, 1,2-benzenidicarboxylic acid, germacrene $\mathrm{B}$ and pentadecane. Active compounds such as hydroxyl-1-8-cineole, glucopyranosides, $(1 \mathrm{R}, 2 \mathrm{R}, 4 \mathrm{R})$ and $(1 \mathrm{~S}, 2 \mathrm{~S}$, 4R)-trans2-hydroxyl-1,8-cineole of A. galanga are accountable for its exclusive aroma [7].

Alpinia galanga also contains many flavonoids and a wide range of volatile oils. The rhizome of Alpinia galanga is used in many regions for relieving toothache, muscular swelling, rheumatism, abdominal pain [8]. Terpinen-4-ol is one of the most active compounds of Alpinia galanga and this plant also contains, saponins, terpenoids, phenolics, flavonoids, carbohydrates, alkaloids, glycosides, phytosterols [7]. Ethanolic extract of Alpinia galanga isolates galango flavonoid [9] and also have several medicinal active ingredients that have the potential of antitumor, antifungal, antioxidant, hypoglycemic, gastroprotective, hypolipidemic, antiinflammatory activity [10]. It also had been reported that methanolic and aqueous extracts of Alpinia galanga showed significant free radical scavenging activity against DPPH radical, have strong superoxide anion scavenging activity and also have metal chelating activity. The ethanolic extract of galanga was also found to be effective in inhibiting a-glucosidase and an amylase (in vitro) and posse's good antimicrobial activity [11]. It also had been reported that Alpinia galanga improve cognitive performance in animals [12]. 
Harvesting the crop at 42 mo subsequent to planting was the perfect for realizing maximal rhizome (45.4 t/ha) and oil (127.4 liters/ha) yields, and for make oil of acceptable quality $(27.1 \%$ cineole [eucalyptol]). After 39 mo planting, a considerable amount of oil was collected from the roots (19.5 t/ha), and from the shoot yield ( 40.5 t/ha) from the plant of Alpinia galanga [13].

This review was prepared by searching various scientific database, Science direct, Pubmed, Google Scholar by using the keywords Alpinia galanga, Alpinia galanga pharmacological studies, Alpinia galanga toxicological studies, Alpinia galanga chemical constituents. The main aim was to provide an updated and comprehensive review regarding morphological, chemical and pharmacological activities of Alpinia galanga.

\section{Common names}

Arabic-Kholinjan Kabeer;

Burma-Padagogi;

Kannada-Ditrnparrasm;

Cambodia-Rumdeng, Pras;

English-Greater Galanga;

Indonesia-Langkuas (general);

French-Galanga;

Sanskrit-Barakulanjar;

Sinhala-Aratta;

Mahaaratta-Kaluwala;

Malaysia-Lengkuas, Puar;

Philippines-Languas (general), Pal-la (Mandaya);
Thailand-Kha, khayuak (northern);

Tamil-Perarattai;

Telugu-Peddadumparashtram;

Marathi-Koshtkulayan;

Malayalam-Arratta, peraratta. kol-inj;

Gujarati-Kulinjan [14]

\section{Botanical description}

A. galanga is a perennial, robust, tillering, rhizomatous herb, growing up to $3.5 \mathrm{~m}$ tall, with a subterranean, creeping, copiously branched aromatic rhizome. The rhizomes are $2.5-10.0 \mathrm{~cm}$ thick, reddish-brown externally, and light orange-brown internally. The aerial leafy stem (pseudo-stem) is erect, formed by the rolled leaf sheaths. Leaves are $23-45$ by $3.8-11.5 \mathrm{~cm}$, alternate, distichous, oblong-lanceolate, acute and glabrous. The inflorescence is a terminal many-flowered raceme; the flowers are fragrant, $3-4 \mathrm{~cm}$ long, yellow-white; the fruit is globose to an ellipsoidal capsule, 1$1.5 \mathrm{~cm}$ in diameter, orange-red to wine red. Rhizome anatomy shows a central stele surrounded by an outer cortical zone. Fibrovascular bundles are distributed throughout the cortex and stele. Numerous resin canals are also present. Its chromosome number is $2 \mathrm{n}=48$ [15]. Much variability may exist as the species occurs naturally in many countries under varying agro-ecological situations; however, information is lacking. Cultivars with pink to red rhizomes and with yellow-white rhizomes are known. The pseudo-stems of white cultivars reach about $3 \mathrm{~m}$ in height, and the rhizomes $8-10 \mathrm{~cm}$ in diameter. The red cultivars, which are more common and widely used, reach 1-1.5 $\mathrm{m}$ in height and the rhizomes $1-2 \mathrm{~cm}$ in diameter. This occurs wild and under cultivation in Java, Borneo and the Philippines [16]. The morphology of the plants has been described in fig. 1.
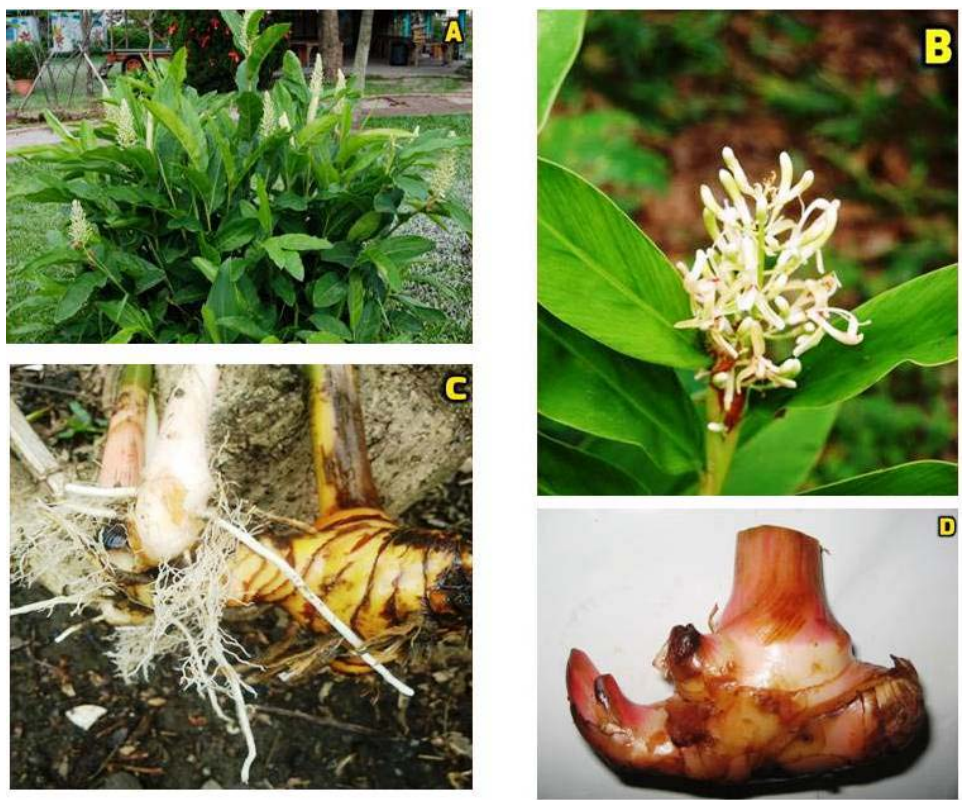

Fig. 1: (A) Whole plant of Alpinia galanga (B) Flower of Alpinia galanga, (C) Rhizome of Alpinia galanga (D) Dried rhizome of Alpinia galanga, @ tropical plants database, ken fern tropical the ferns info. 2019-01-12

\section{Taxonomy}

Alpinia galanga belongs to the Tribe Alpinieae of Alpinioideae subfamily under the Zingiberaceae family of Zingiberales order. Alpinia galanga is known by several synonyms such as Amomum galanga, Alpinia viridiflora, Maranta galanga, Languas galanga, Languasvulgare. It is known by several common names such as Kulanjan in Hindi, Dhumarasmi in Kannada, Kulingjan in Bengali, Kulinjan in Gujrati, Arattha in Malayalam, Pera-rattai in Tamil,
Dhoomraasmi in Kannad, Pedda-dhumpa in Telugu, Mahabaracach, SugandhaVacha, Rasna in Sanskrit, Greater galanga in English.

\section{Geographical distribution}

It is found in Indonesia, India, China, and Arabic gulf areas, Malaysia, Egypt, and Sri Lanka. It grows in open sunny places, forests, and brushwood. It is commonly cultivated in the mid and low-country in Sri Lanka. The plant is distributed in Himalaya and Southern region 
of the Western Ghats in India. It is often cultivated in Konkan and North Kanara [17].

\section{Traditional uses}

Alpinia galanga has been used for the treatment of bronchitis, coryza, cholera, eczema, gastritis, morbili, otitis pityriasis versi color, and ulcers. The seed of Alpinia galanga is used for emaciation and to clear the mouth, trigger the appetite, digestive power and acts as a purgative. Alpinia galanga is a significant medicinal plant to treat several diseases, including microbial infections, rheumatic pains, inflammations, chest pain, and dyspepsia, fever, burning of the liver, kidney disease, tumor, diabetes and even HIV [4]. The plant has an active role in the treatment of eczema, bronchitis, otitis internal, gastritis, ulcers, and cholera. The seed is used for emaciation and to clean the mouth. It stimulates the digestive power, appetite and acts as a purgative. The rhizome is generally used as a spice. It is also a good source of essential oil. The flowers and young shoots are also used as a vegetable or as a spice [14].

\section{Phytoconsituents}

The rhizome contains essential oils, the constituents of which are methyl cinnamate, p-methane-1,8-epoxy-acethoxychavicol acetate, alpinin, kaempferide, 3-dioxy 4-methoxy flavone, pinene, camphor,pineol, galangin, (1'S)-1'-acetoxychavicol acetate, (1'S)-1'acetoxyeugenol acetate, 1'-acetoxychavicol acetate, 1'acetoxyeugenol acetate, D-camphor, chavicol, chavicol acetate, 1,8cineole, 3-hydroxy-1,8-cineole glucopyranosides, (1R,2R,4S), (1S,2S,4R)-trans-2-hydroxy-1,8-cineole-D-glucopyranosides, (1R,3S,4S)-trans-3-hydroxy-1, 8-cineole-D-glucopyranoside, trans coniferyldiacetate, trans-p-coumaryldiacetate, di-(p-hydroxy-cisstyryl) methane, eugenol acetate, trans $\beta$-faranesene, 7-hydroxy-3,5dimethoxy flavone, 4-hydoxybenzyldehyde, 1 '-hydroxychavicol acetate, p-hydroxycinammaldehyde, isorhamnetin, kaempferol, kaempferol-4'-methylether, methylcinnamate, kaempferol-7'methylether, methyleugenol, $\alpha$-thujene, $\alpha$-pinene, 3-carene, $\beta$ pinene, camphene, myrcene, p-cymene, borneol, $\alpha$-terpineol, 4terpineol, fenchyl acetate, bornyl acetate, $\alpha$-humulene, zerumbone.

Two skeletal diterpenes, named galanga $A$ and $B$, and 2 labdane type diterpenes, named galanolactone and (E)- $\beta$ (17), 12-labdiene-15,16dial, were isolated from A. galanga together with (E)-(17)- $\beta$ epoxylabd-12-ene 15,16-dial. One of the aromatic principles of A. galanga rhizome was confined and analyze as 1'-acetoxychavicol diacetate [18]. Major biomolecules isolated from Alpinia galanga and their mechanism of action has been shown in table 1 .

Table 1: Shows major biomolecules isolated from Alpinia galanga and their mechanism of action

\begin{tabular}{|c|c|c|c|}
\hline Name of the compound & $\begin{array}{l}\text { Type of the } \\
\text { compound }\end{array}$ & Pharmacological activity & References \\
\hline $\begin{array}{l}\text { 1,7-bis(4-hydroxyphenyl)-1,4, } \\
\text { 6-heptatrien-3-one (BHPHTO) } \\
\text { And bisdemethoxycurcumin } \\
\text { (BDMC) }\end{array}$ & $\begin{array}{l}\text { Curcuminoid } \\
\text { (natural phenols) }\end{array}$ & Inhibit proliferation of human melanoma A2058in the cell viability assay. & [19] \\
\hline 1'-acetoxychavicol acetate & Phenylpropanoid & $\begin{array}{l}\text { Induces apoptosis in myeloid leukemia cells. In NB4 cells, ACA-induced } \\
\text { apoptosis is in association with the loss of mitochondrial transmembrane } \\
\text { potential and activation of caspase-9, hence, ACA-induced death signalling } \\
\text { is mediated through a mitochondrial oxygen stress pathway. In addition, } \\
\text { ACA activated Fas-mediated apoptosis by inducing of casapse- } 8 \text { activity. }\end{array}$ & [20] \\
\hline $1^{\prime} S-1^{\prime}$-acetoxyeugenol acetate & Phenylpropanoid & In RBL-2H3 cells, participate in the late phase of type I allergic reactions & [21] \\
\hline$p$-hydroxycinnamaldehyde & Phenylpropanoid & $\begin{array}{l}\text { Potential therapeutic agent for the treatment of Osteoarthritis as it has an } \\
\text { effect on human chondrocytes }\end{array}$ & [22] \\
\hline 1'S-1'-acetoxychavicol acetate & Phenylpropanoid & $\begin{array}{l}\text { Acts as efflux pump inhibitor which provokes resistance in mycobacterium } \\
\text { and hence it acts as a new target for the discovery of anti-TB agents }\end{array}$ & [23] \\
\hline $\begin{array}{l}\text { 1'S-1'-acetoxychavicol acetate } \\
\text { (ACA) }\end{array}$ & Phenylpropanoid & Inhibition of the constitutive activation of NF- $\mathrm{kB}$ through & [24] \\
\hline $\begin{array}{l}\text { 1'S-1'-acetoxychavicol acetate } \\
\text { (ACA) }\end{array}$ & Phenylpropanoid & Antiplasmid activity against multi-drug resistant bacteria. & [25] \\
\hline
\end{tabular}

\section{Pharmacological activities}

\section{Antimicrobial activities}

Aqueous extract of $A$. galanga shows significant action against Escherichia coli, Klebsiella pneumonia, S. aureus, Pseudomonas aeruginosa, and Streptococcus pyogenes except for Staphylococcus epidermidi [26]. Essential oil had shown significant activity against Streptococcus suis, Staphylococcus aureus, Pseudomonas aeruginosa, Erysipelothrix rhusiopathiac, Pasteurella multocida, E. coli, and Arcanobacterium pyogenes, the effects were attributed to 1,8-cineole, 4-ally phenylacetate and $\alpha$-bisabolene [27]. Oven-dried ethanol extract from Alpinia galangal flower was the most powerful against $S$. aureus with the minimum inhibitory concentration (MIC) ranging from $0.352-0.547 \mathrm{mg} / \mathrm{ml}$ and inhibition zone of about $26-31 \mathrm{~mm}$. No antimicrobial activity was recognized on E. coli 0157:H7 and Salmonella. Long-term antimicrobial activity of oven-dried samples extracted with ethanol was the largest with an inhibition zone of $8.94 \mathrm{~mm}$ and MIC of $1.457 \mathrm{mg} / \mathrm{ml}$. In contrast, freeze-dried samples extracted with ethanol exhibited the lowest overall antimicrobial activity (7.05 $\mathrm{mm}$ and $2.470 \mathrm{mg} / \mathrm{ml}$ ) [28].

The Alpinia galanga ethanolic extract had an active inhibitory effect against $S$. aureus. The minimum inhibitory concentration (MIC) of the galanga extract was $0.325 \mathrm{mg} / \mathrm{ml}$ and the minimum bactericidal concentration (MBC) was $1.3 \mathrm{mg} / \mathrm{ml}$ using the broth dilution approach. Transmission electron microscopy demonstrated that the Alpinia galangaextract generate both outer and inner membrane destruction, and cytoplasm coagulation. Interruption of the cytoplasmic membrane properties was resolved through the discharge of cell materials including nucleic acids [29]. Alpinia galangahave antifungal action against fungi resist the common antifungal products like amphotericin B and ketoconazole [30]. It exerted a concentration-dependent inhibition of the production of zoonotic dermatophytes and the yeast-like Candida albicans [31] Ethanolic extract of A. galanga have phytotoxic action against Lemna minor and antifungal action against Trichophyton longifusus [32]. It also shows antifungal action against phytopathogenic fungi, Colletotric hummusae, Candida albicans, and Fusariumoxy sporum, at a concentration of $10 \mathrm{mg} / \mathrm{ml}$ [33]. Methanolic extract of $A$. galanga and 1 'S-1'-Acetoxychavicol acetate showed strong inhibitory action against human immunodeficiency virus type-1 (HIV-1) and against human cytomegalovirus (HCMV). At a concentration of $1000 \mathrm{ug} / \mathrm{ml}$, chloroform extract of Alpinia galangal has shown good inhibition against Entamoeba histolytica. It also shows activity against Giardia intestinalis, the minimum inhibitory concentration (MIC) was $125 \mu \mathrm{g} / \mathrm{ml}[34,35]$. Hexane, ethyl acetate and chloroform extracts $(100 \mu \mathrm{g} / \mathrm{ml})$ of Alpinia galanga rhizomes exhibited important action against promastigotes of L. donovaniin vitro [36]. 


\section{Anti-ulcer}

A study reported Gastric antisecretory, antiulcer and cytoprotective properties of ethanolic extract of Alpinia galanga willd in rats. They said rhizomes of A. Galanga are used widely in Arabian and Unani systems of medicine to treat stomach disorders. The ethanolic extract also significantly reduced gastric secretion and showed marked cytoprotective activity; it is suggested that these properties may be responsible for the antiulcer activity of Alpinia galanga. A study reported treatment on cytological and biochemical changes induced by cyclophosphamide in mice by the effect of Alpinia galanga from the ethanolic extract. The rhizomes of Alpinia galanga are used as a spice and in traditional medicine to treat dyspepsia, gastralgia, sea sickness, and abdominal colic, and as an antiinflammatory, anti-neoplastic, digestive and tonic [37].

\section{Anti-inflammatory}

Evaluation of the anti-inflammatory potential of the rhizome of Alpinia galanga linn. was carried out. The anti-inflammatory activities of total aqueous extract (TAQ) and total alcoholic extract (TAE) from Alpinia galanga rhizomes were accessed in acute (carrageenan-induced paw edema; M1) and sub-acute (cottonpellet-induced granuloma; M2) rat models [38]. The analgesic activity and anti-inflammatory of the topical preparation of a methanolic extract of Alpinia galangal wild were reported. The antiinflammatory activity was evaluated against Carrageenan-induced edema in rats and in a formalin test. Piroxicam gel and methyl salicylate ointment were studied as positive controls for antiinflammatory and analgesic activities, respectively [39]. It is reported that the methanolic and phenolic extract of the rhizome of Alpinia galanga exhibit antidiabetic and anti-inflammatory properties [40]. The p-hydroxy cinnamaldehyde obtained from Alpinia galanga acetone extracts has a pharmacological effect on human chondrocytes. Osteoarthritis (OA) is the most familiar form of arthritis and influence millions of population globally. Patients have habitually been treated with non-steroidal anti-inflammatory drugs (NSAIDS), but these are correlated with significant side effects [41].

\section{Hepatotoxicity}

The treatment with the crude extract of Alpinia galangal due to paracetamol hepatotoxicity in rats was reported. This research was conducted to detect the hepatoprotective effect of the crude extract of Alpinia galangal at 200 and $400 \mathrm{mg} / \mathrm{kg}-1$ against paracetamolinduced hepatotoxicity in rats [31].

\section{Anti-oxidant}

A study of antioxidative components in extracts of Alpinia galanga (L.) and it states $50 \%$ ethanol in water was studied for its antioxidant activity and composition in comparison with two other samples based on the essential oil and water extract. The antioxidant activities were resolved by using methods like oxygen radical absorbance capacity (ORAC) and the 2, 2-diphenyl-1picrylhydrazyl (DPPH). The ethanolic extract produces the highest DPPH free radical scavenging capacity as well as the highest ORAC value when compared to the water extract and the essential oil [42]. It was studied that the antioxidant activity of methanol extracts of Alpinia galangaeaves was evaluated for total phenolic content. The AOA was investigated using 1, 1-diphenyl-2 picrylhydrazyl (DPPH), ferrous ion chelating, reducing power (RP), as well as beta-carotene bleaching assays. According to wong et al. Alpinia galangaeaves and flowers showed highest chelating and beta-carotene bleaching abilities. Alpinia galangal flowers extract showed the largest zone of inhibition of Micrococcus luteus. Only the extract from Alpinia galangal rhizome showed antifungal action against Aspergillusniger. The antimicrobial activities were screened by using disc diffusion method [43]. One more investigation indicates that Alpinia galangal rhizome extract exhibited the highest antioxidant activity in all the assays than Alpiniacalcarata [44].

\section{Antiplatelet}

Constituents of Alpinia galangal exerted platelet activating factor (PAF) antagonists. In rabbit platelets, methanolic extract showed significant inhibitory effects on PAF with IC50 value of $5.5 \mathrm{ug} / \mathrm{ml}$ [45].

\section{Antitumor}

1,7-bis (4-hydroxyphenyl)-1,4,6-heptatrien-3-one (BHPHTO) and bisdemethoxycurcumin (BDMC) from the rhizomes of $A$. galanga were examined for their bio effectivenesses on the human melanoma A2058 and inhibited the proliferation of melanoma cells in the cell growth assay significantly. The tests to B16-F10 cell line was also taken in research and showed minor inhibitory results of cellular tyrosinase activities and melanin contents [19].

\section{Antiallergic}

Alpinia galangal was found to be effective in the treatment of allergy and the isolated compounds which extract inhibit the release of antigen IgE mediated in passive cutaneous anaphylaxis reactions in mice [21].

\section{Anti-diabetic}

The investigation was carried out to study hypoglycemic effects of Alpinia galangal rhizome on blood glucose levels in rabbits. Powdered rhizome and its methanol and aqueous extracts significantly lowered the blood glucose in normal rabbits [46].

\section{Anti-HIV}

Anti-human immunodeficiency virus type 1 replication by blocking Reverse Transport from 1' S-1'acetoxychavicol acetate isolated from Alpinia galanga rhizomes extract[47].

\section{Immunomodulator}

Study reported Immunostimulating activity of the hot watersoluble polysaccharide extracts of Alpinia galanga. Alpinia galanga (L.) Willd. were tested for their immunostimulating activity in mice [48].

\section{Nitric oxide (NO) inhibition}

An $80 \%$ acetone-water extract of galanga showed NO inhibitory action in mouse peritoneal macrophages. Three neolignans have been isolated from the acetone extract (galanganal, galanganol A and B) and a seaquineolignan, galanganol-C). The NO-inhibition activity has at least partly been attributed to the neolignans. Six diarylheptanoids of galanga are reported to be inhibitors of NO production in the lipopolysaccharide-activated macrophage cell line RAW 264. Active diarylheptanoids suppressed the expression of the inducible NO synthase protein and mRNA. Such results at least partly explain the use of galanga for inflammation reduction. ACA has been shown to have potent NO-inhibitory activity in lipopolysaccharide-activated mouse peritoneal macrophages [49].

\section{Cardioprotective}

The experimental evidence shows that Galangin has strong antioxidant activity, and it can maintain cell membrane integrity, and ameliorate oxidative stress induced by high-dose of Doxorubicin administration [50].

\section{Pharmacology of aqueous extract}

Aqueous extract of A. galanga showed significant activity against Klebsiella pneumonia, Escherichia coli, Pseudomonas aeruginosa, $S$. aureus and Streptoccocus pyogenes except Staphylococcus epidermidis [26]. The aqueous fraction had a lower cell proliferation and splenocyte proliferation stimulatory effect [51]. 1'S-1'acetoxychavicol acetate and 1 'S-1'-acetoxyeugenol acetate from aqueous extract of rhizome inhibited the release of hexosaminidase and the antigen-IgE-mediated TNF-alpha and IL-4 production in passive cutaneous anaphylaxis reactions in mice [21]. Aqueous and hydroalcoholic extracts from leaves and rhizomes of above species possesses key factors responsible for antinociceptive (reducing sensitivity to painful stimuli) and antiallergic properties [52].

The aqueous extract was used for evaluation of anthelmintic activity, Extraction was made by maceration, and a freshly prepared extract was first used for in vitro anthelmintic activity against earth warms by using Albendazol as standard. Current study found that the plant Alpinia galanga Willd. possess good anthelmintic activity in a dosedependent manner [53]. 


\section{Toxicological studies}

Acute $(24 \mathrm{~h}$ ) and chronic (90 d) oral toxicity studies on the ethanolic extracts of the rhizomes of Alpinia galangal were carried out in mice. Acute dosages were $0.5,1.0$, and $3 \mathrm{~g} / \mathrm{kg}$ body weight while the chronic dosage was $100 \mathrm{mg} / \mathrm{kg} /$ day as the extract. All external morphological, hematological, and spermatogenic changes, in addition to body weight and vital organ weights, were recorded. During this investigation, no significant mortality as compared to the controls was observed. The weight gain in the A. galanga treated animals was significant as in the control group. Hematological studies revealed a significant rise in the RBC level of A. galangatreated animals as compared to the controls. The gain in weights of sexual organs and increased sperm motility and sperm counts were observed groups of extract-treated male mice, however, these changes were highly significant in the A. galanga-treated group. Extracts failed to show any spermatotoxic effects [54].

An acute oral toxicity study was carried out on the methanolic extract of Alpinia galanga residue as per OECD guidelines. The dose of $5000 \mathrm{mg} / \mathrm{kg}$ was studied in the present study to know the $\mathrm{LD}_{50}$ between 2000-5000 $\mathrm{mg} / \mathrm{kg}$ as the drug is popular and extensively used, this information will help in safeguarding the human health. As there is no mortality even at the highest dose tested the $\mathrm{LD}_{50}$ was estimated to be more than 5000 $\mathrm{mg} / \mathrm{kg}$ and accordingly a dose of $500 \mathrm{mg} / \mathrm{kg}$ was chosen for the antiinflammatory study [55]. The present study revealed the presence of complex phytochemical constituents including phenols and flavanoids. The acute toxicity results have classified the test material to fall under the hazard category $2000 \mathrm{mg} / \mathrm{kg}$ [56].

\section{Quality issues and adulteration}

Little is known about the quality issues pertaining to galanga. The major point to be remembered is that three species of Alpinia-A. galanga, A. calcarata, and A. officinarum-are all treated as galanga in the world market. No differentiation is made either by the exporting countries or by the importing countries; quality and flavor-wise, they are similar and their medicinal properties are also similar. In the traditional Indian Ayurvedic medicine, all three species are used as the source for the raw drug raasna. It has been reported the pharmacognostical standardization and evaluation of galanga rhizome as a valuable tool for identification, authentication, and detection of adulterants and quality control of the drug. Dried powdered rhizome is sometimes adulterated with other species such as A. Calcarata, A. Conchigera, A. Mutica, A. Nigra, A. Rafflesiana and A. Scabra. The fruits of A. galangaare used in traditional Chinese medicine, but the dry fruits are easy to adulterate with other species that are used as medicine in local areas. The dry fruits of the adulterants are very similar in odour, morphology, chemical constituents and anatomical characters and they are difficult to distinguish. Scientist has characterized A. galanga and the species used as adulterant using nuclear ribosomal DNA internal transcribed spacer (nrDNA ITS) region sequences, and the molecular markers are used to distinguish the drug at DNA level. Galanga rhizome, extracted oil, and oleoresin are given the regulatory status 'generally regarded as safe' (GRAS) in the USA Researchers have listed the application of A. galanga as herbal medicines in the treatment of various ailments [57].

\section{Dosage and safety aspects}

The drug is conventionally considered to be safe at the dosage of Kulinjan powder 1 to 2 gm daily.

\section{CONCLUSION}

Alpinia galangal has vast biological potential; there are various phytoconstituent present in the plant which is responsible for pharmacological and medicinal properties. Since A. galanga has been known for its broad range of biological activity. Further research should be carried out on formulating the bioactive compounds of $A$. galanga in order to use their practical clinical applications, which can be used for the wellbeing of mankind.

\section{ACKNOWLEDGMENT}

The authors express their deep sense of gratitude to Faculty of
Pharmacy, Integral University, Lucknow for their encouragement and support. The university has provided a manuscript communication number for the further reference (IU/RandD/2018MCN000532).

\section{AUTHORS CONTRIBUTIONS}

All the author have contributed equally

\section{CONFLICT OF INTERESTS}

\section{Declared none}

\section{REFERENCES}

1. Wyk B van, Wink M. Phytomedicines, herbal drugs, and poisons. Chicago: University of Chicago Press; 2015.

2. Vaidya ADB, Devasagayam TPA, Bhavan BV, Prakashananda S. Current status of herbal drugs in India: an overview. J Clin Biochem Nutr 2007;41:1-11.

3. Jantan I bin, Yassin MSM, Chin CB, Chen LL, Sim NL. Antifungal activity of the essential oils of nine zingiberaceae species. Pharm Biol 2003;41:392-7.

4. Verma RK, Mishra G, Singh P, Jha KK, Khosa RL. Alpinia galanga-an important medicinal plant: a review. Der Pharm Sin 2011;2:142-54.

5. Baldo DEB, Serrano JE, Diomerl C, Baldo EB. Screening for the intestinal anti-inflammatory activity of Alpinia galanga against acetic acid-induced colitis in mice (Mus musculus). J Med Plants Stud 2016;4:72-7.

6. Indrayan A, Agrawal P, Rathi A, Shatru A. Nutritive value of some indigenous plant rhizomes resembling ginger. Nat Prod Radiance 2009;8:507-13.

7. Chudiwal AK, Jain DP, Somani RS. Alpinia galanga Willd.-An overview on phytopharmacological properties. Ind J Nat Prod Res 2010;1:143-9.

8. Sharma PK, Singh V, Ali M, Kumar S. Evaluation of antinociceptive and anti-inflammatory activities of methanolic extract of alpinia galanga rhizomes in animal models. Int J Pharm Sci Res 2015;6:3103-8.

9. Jaju S, Indurwade N, Sakarkar D, Fuloria N, Al M. Isolation of galangogalloside from rhizomes of Alpinia galanga. Int J Green Pharm 2009;3:144-7.

10. Singh YR, Kalita JC. Effects of the methanolic extract of alpinia galanga from manipur (India) on the uterus of ovariectomised C3H albino mice. Int Res J Pharm 2012;3:423-7.

11. Srividya A, Dhanabal S, Satish kumar MN, Parth Kumar HB. Antioxidant and antidiabetic activity of alpinia galanga. Int J Pharmacogn Phytochem Res 2010;3:6-12.

12. Saha S, Banerjee S. Central nervous system stimulant actions of Alpinia galanga (L.) rhizome: a preliminary study. Indian J Exp Biol 2013;51:828-32.

13. Garg S, Gupta D, Sadhidhara K, Meha V. Alpinia galanga L.composition of essential oil from flowers. Indian Perfum 2003;47:147-9.

14. Arambewela L, Wijesinghe A. Srilankan medicinal plant monographs and analysis, alpinia galanga. 10th ed. Colombo: Industrial Technology Institute and National Science Foundation; 2006.

15. Ravindran P, Pillai G, Babu K, Divakaran M, Malhothra S, Ochatt $\mathrm{S}$, et al. Minor and under-utilized spices and herbs. Breed Neglected Under-Utilized Crop Spices Herbs 2007;1:299-373.

16. Scheffer J. Monoterpenes in the essential rhizome oil of Alpinia galanga (L.) Willd. Sci Pharm 1981;49:337-46.

17. Rastogi RP, Mehrotra BN, Sinha S, Pant P, Seth R, (India) CDRI, et al. Compendium of Indian medicinal plants. New Delhi Central Drug Research Institute and Publications and Information Directorate; 1990.

18. Lee CC, Houghton P. Cytotoxicity of plants from Malaysia and Thailand used traditionally to treat cancer. J Ethnopharmacol 2005;100:237-43.

19. Lo CY, Liu PL, Lin LC, Chen YT, Hseu YC, Wen ZH, et al. Antimelanoma and antityrosinase from Alpinia galanga constituents. Sci World J 2013;3:186505.

20. Ito K, Nakazato T, Murakami A, Yamato K, Miyakawa Y, Yamada $\mathrm{T}$, et al. Induction of apoptosis in human myeloid leukemic cells 
by 1 -acetoxychavicol acetate through a mitochondrial-and fasmediated dual mechanism. Clin Cancer Res 2004;10:2120-30.

21. Matsuda H, Morikawa T, Managi H, Yoshikawa M. Antiallergic principles from Alpinia galanga: structural requirements of phenylpropanoids for inhibition of degranulation and release of TNF-alpha and IL-4 in RBL-2H3 cells. Bioorg Med Chem Lett 2003;13:3197-202.

22. Phitak T, Choocheep K, Pothacharoen P, Pompimon W, Premanode B, Kongtawelert $P$. The effects of phydroxycinnamaldehyde from Alpinia galanga extracts on human chondrocytes. Phytochemistry 2009;70:237-43.

23. Roy SK, Pahwa S, Nandanwar H, Jachak SM. Phenylpropanoids of Alpinia galanga as efflux pump inhibitors in mycobacterium smegmatis mc2 155. Fitoterapia 2012;83:1248-55.

24. In L LA, Arshad NM, Ibrahim H, Azmi MN, Awang K, Nagoor NH. 1 '-Acetoxychavicol acetate inhibits the growth of human oral carcinoma xenograft in mice and potentiates cisplatin effect via proinflammatory microenvironment alterations. BMC Complement Altern Med 2012;12:1144.

25. Latha C, Shriram VD, Jahagirdar SS, Dhakephalkar PK, Rojatkar SR. Antiplasmid activity of 1 -acetoxychavicol acetate from Alpinia galanga against multi-drug resistant bacteria. J Ethnopharmacol 2009;123:522-5.

26. Turker A, Usta C. Biological activity of some medicinal plants sold in turkish health-food stores. Biotechnol Biotechnol Equip 2006;20:105-13.

27. Tachakittirungrod S, Chowwanapoonpohn S. Comparison of antioxidant and antimicrobial activities of essential oils from hyptis suaveolens and alpinia galanga growing in Northern Thailand. C J Nat Sci 2007;6:31-42.

28. Hsu WY, Simonne A, Weissman A, Kim JM. Antimicrobial activity of greater galanga [Alpinia galanga (Linn.) Swartz.] flowers. Food Sci Biotechnol 2010;19:873-80.

29. Oonmetta Aree J, Suzuki T, Gasaluck P, Eumkeb G. Antimicrobial properties and action of galanga (Alpinia galanga Linn.) on staphylococcus aureus. LWT-Food Sci Technol 2006;39:1214-20.

30. Ficker CE, Smith ML, Susiarti S, Leaman DJ, Irawati C, Arnason JT. Inhibition of human pathogenic fungi by members of Zingiberaceae used by the Kenyah (Indonesian Borneo). J Ethnopharmacol 2003;85:289-93.

31. Trakranrungsie N, Chatchawanchonteera A, Khunkitti W. Ethnoveterinary study for an antidermatophytic activity of Piper betle, alpinia galanga and allium ascalonicum extracts in vitro. Res Vet Sci 2008;84:80-4

32. Khattak S, Saeed-Ur-Rehman, Ullah Shah H, Ahmad W, Ahmad M. Biological effects of indigenous medicinal plants curcuma longa and Alpinia galanga. Fitoterapia 2005;76:254-7.

33. Taechowisan T, Lumyong S. Activity of endophytic actinomycetes from roots of zingiber officinale and alpinia galanga against phytopathogenic fungi. Artic Ann Microbiol 2003;53:291-8.

34. Sawangjaroen N, Subhadhirasakul S, Phongpaichit S, Siripanth C, Jamjaroen K, Sawangjaroen K. The in vitro anti-giardial activity of extracts from plants that are used for self-medication by AIDS patients in southern Thailand. Parasitol Res 2005;95:17-21.

35. Sawangjaroen N, Phongpaichit S, Subhadhirasakul S, Visutthi M, Srisuwan N, Thammapalerd N. The anti-amoebic activity of some medicinal plants used by AIDS patients in southern Thailand. Parasitol Res 2006;98:588-92.

36. Kaur A, Singh R, Dey CS, Sharma SS, Bhutani KK, Singh IP Antileishmanial phenylpropanoids from Alpinia galanga (Linn.) willd. Indian J Exp Biol 2010;48:314-7.

37. Qureshi S, Shah AH, Ahmed MM, Rafatullah S, Bibi F, Al-Bekairi AM. Effect of alpinia galanga treatment on cytological and biochemical changes induced by cyclophosphamide in mice. Int J Pharmacogn 1994;32:171-7.
38. Satish R, Dhananjayan R. Evaluation of anti-inflammatory potential of the rhizome of alpinia galanga linn. Biomedicine 2003;23:91-6.

39. Nagashekhar M, Shivprasad H. Anti-inflammatory and analgesic activity of the topical preparation of alpinia galanga willd. Biomed Contents 2005;1:63-9.

40. Jaju S, Indurwade N, Sakarkar D, Fuloria N, Ali M, Das S, et al. Galangoflavonoid isolated from the rhizome of alpinia galanga (L) Sw (Zingiberaceae). Trop J Pharm Res 2010;8:545-50.

41. Pompimon W, Jomduang J, Prawat U, Mankhetkorn S. Antiphytopthora capsici activities and potential use as an antifungal in agriculture of alpinia galanga swartz, curcuma longa linn, boesenbergia pandurata schut and chromolaena odorata: bioactivities guided isolation of active ingredients. Am J Agric Biol Sci 2009;4:83-91.

42. Mahae N, Chaiseri S. Antioxidant activities and antioxidative components in extracts of alpinia galanga (L.) Nat Sci 2009;43:358-69.

43. Wong LF, Lim YY, Omar M. Antioxidant and antimicrobial activities of some alpina species. J Food Biochem 2009;33:83551.

44. Melanathuru V, Rengarajan S, Thangavel N. Comparative study of the antioxidant and anticancer activity of alpinia calcarata and alpinia galanga. Int J Pharm Pharm Sci 2017;9:186-93.

45. Jantan I, Rafi IAA, Jalil J. Platelet-activating factor (PAF) receptor-binding antagonist activity of Malaysian medicinal plants. Phytomed 2005;12:88-92.

46. Akhtar RA, Reddy AB, Maywood ES, Clayton JD, King VM, Smith $\mathrm{AG}$, et al. Circadian cycling of the mouse liver transcriptome, as revealed by cDNA microarray, is driven by the suprachiasmatic nucleus. Curr Biol 2002;12:540-50.

47. Ye Y, Li B. 1'S-1'-acetoxychavicol acetate isolated from alpinia galanga inhibits human immunodeficiency virus type 1 replication by blocking rev transport. J Gen Virol 2006;87:2047-53.

48. Bendjeddou D, Lalaoui K, Satta D. Immunostimulating activity of the hot water-soluble polysaccharide extracts of anacyclus pyrethrum, alpinia galanga, and citrullus colocynthis. J Ethnopharmacol 2003;88:155-60.

49. Itokawa H, Morita H, Midorikawa I, Aiyama R, Morita M. Diarylheptanoids from the rhizome of Alpinia officinarum hance. Chem Pharm Bull 1985;33:4889-93.

50. Ravichandra V, Hanumantharayappa B, Papasani MRV. Evaluation of the cardioprotective activity of galangin against doxorubicin-induced cardiomyopathy. Int J Pharm Pharm Sci 2014;6:86-90.

51. Jain AP, Pawar RS, Lodhi S, Singhai AK. An immunomodulatory and anti-oxidant potential of alpinia galanga linn. rhizomes. Pharmacogn Commun 2012;2:30-7.

52. Arambewela LSR, Arawwawala LDAM, Ratnasooriya WD. Antinociceptive activities of aqueous and ethanolic extracts of Alpinia calcarata rhizomes in rats. J Ethnopharmacol 2004;95:311-6.

53. Patil NP, Bhapkar PH, Maheshwari KM, Jagtap PN, Shewale AP, Patil RY. Anthelmintic activity of aqueous extracts of the alpinia galanga willd Rh. Int J Pharm Sci Rev Res 2014;25:72-5.

54. Qureshi S, Shah A, Ageel A. Toxicity studies on alpinia galanga and curcuma longa. Planta Med 1992;58:124-7.

55. Unnisa A, Parveen TD. Anti-inflammatory and acute toxicity studies of the extracts from the rhizomes of alpinia galanga willd. Der Pharm Sin 2012;2:361-7.

56. Subash K, Bhaarathi MG, Rao JN, Vargheese Cheriyan B. Phytochemical screening and acute toxicity study of an ethanolic extract of alpinia galanga in rodents. Int J Med Res Heal Sci 2012;2:93-100.

57. Peter KV. Handbook of herbs and spices. Vol. 3. Newyork: Woodhead; 2006 